any of the relevant equipment want to do this MSc and then go on to do a PhD.

A high proportion of those admitted onto the course have gone on to do admirably well in their subsequent PhD studies, and many have become independent and eminent researchers within their respective fields.

David Andrew Green Division of Applied Biomedical Research, Department of Physiology, King's College London, 4.19 Shepherd's House, Guys Campus, London SE1 1UL, UK e-mail: david.a.green@kcl.ac.uk

\section{Will waste-energy plant be a waste of money?}

SIR - In his entertaining Futures story 'The brown revolution' (Nature 455, 564; 2008), Norman Spinrad waxes eloquent about turning faeces into energy. Some, however, are taking the idea more seriously. Swedish Biogas International is collaborating with Kettering University in Flint, Michigan (hometown of the US ambassador to Sweden, Michael Wood), to create a waste-energy plant that will recycle human faeces and turn them into renewable energy. The project will cost about $\$ 78$ million, with $\$ 4$ million coming from the Michigan Strategic Fund (see http://tinyurl. com/5ngr2c).

However, the value of this technology has been questioned. Taking human faeces, for example, a daily diet of 2,000 calories (8,372 kilojoules) produces an energy residue in the faeces of about 7\% (586 kilojoules) roughly equivalent to the amount of solar energy shining on one square metre for just over seven minutes (see B. B. Desai Handbook of Nutrition and Diet, Dekker, 2000).

Compare this with the energy in a litre of petrol: 32,000 kilojoules. One bowel movement yields the equivalent of $1.8 \%$ of a litre of petrol. We are not going to motor

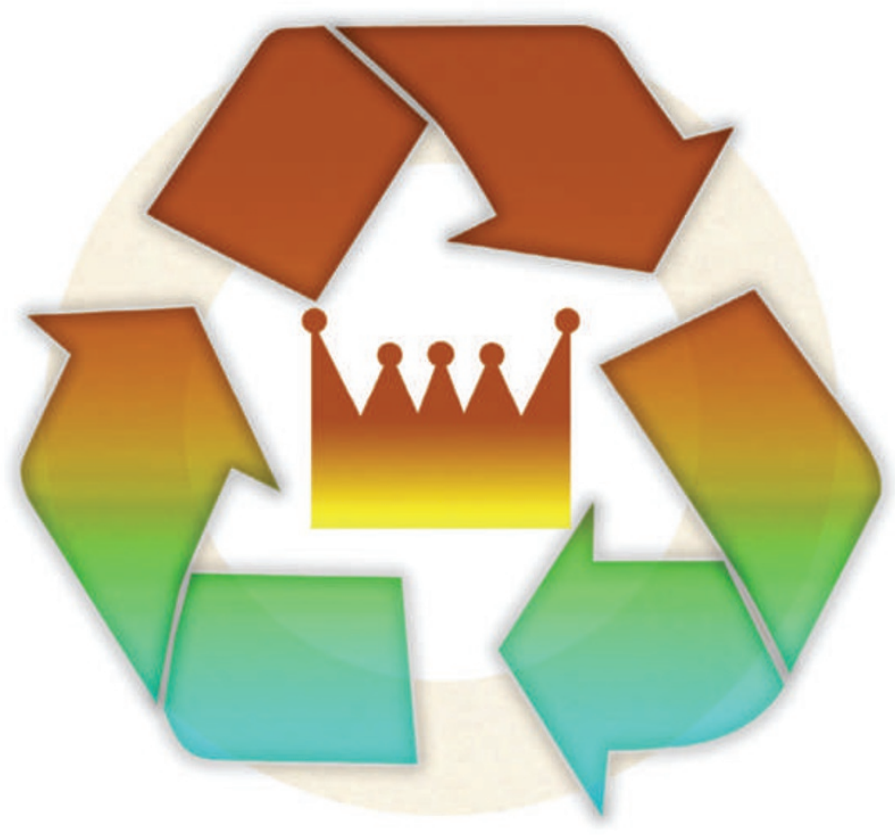

very far on that. Neither does this calculation consider the energy it would take to convert faeces into energy. What is the net energy of the conversion? Is the energy ratio greater than unity, indicating that we are getting more energy out than we are putting in?

Faecal matter should be returned to the soil, from which the food that produced it originated. That closes the cycle, replenishes soil nutrients, and allows us to sustain our ecosystems and lives. Burning it, in whatever form, is akin to flaring off natural gas at the wellhead.

Gene Bazan PO Box 24, Lemont, Pennsylvania 16851, USA e-mail:genebazan@aol.com

\section{Joining a trade union is best way to defend postdoc interests}

SIR - Postdoctoral associations may be needed in many places (Nature 455, 425-428; 2008). However, postdocs in the United Kingdom already have the protection of trade unions, if they choose to join.

The unions are formally recognized by employers and negotiate for their members in areas such as pay, conditions, health and safety. Also, if an employer proposes a major change (such as a merger or department closure), trade unions will offer critical comment not just on the fate of their members but on how science - at the location, nationally and internationally - will be affected. In addition, the unions have considerable resources available with which they can provide advice and legal representation in employment disputes. For example, they recently won a $13 \%$ pay award for UK university academics, including postdocs.

I concede that postdoctoral voices struggle to be heard in unions. An association spanning different unions would be welcome, with useful roles in areas such as postdoc concerns, holding meetings and producing white papers of best practices or policy recommendations.

Being a trade unionist has empowered me. I am at the heart of negotiations, in my case within the UK Medical Research Council. For example, my institute is soon to be merged into the UK Centre for Medical Research and Innovation, and I gave evidence at the recent review on the impact of the new institute. I was talking about science, but I was invited because of my union. If I am made redundant in the merger, I will get legal support to negotiate my redundancy terms. My colleagues who aren't members will not.

Oliver de Peyer Lab 209, Division of Molecular Structure, National Institute for Medical Research, The Ridgeway, Mill Hill, London NW7 1AA, UK e-mail: opeyer@nimr.mrc.ac.uk

\section{Detectors could spot plagiarism in research proposals}

\section{SIR - Your News story 'Entire-} paper plagiarism caught by software' (Nature 455, 715; 2008) follows other reports of systems to detect plagiarism (see M. Errami and H. Garner Nature 451, 397-399; 2008, and S. L. Titus et al. Nature 453, 980-982; 2008). Having all been involved in proposal evaluation, we believe the studies indicate that a textmatching analysis of research proposals could reduce plagiarism in subsequent publications.

For instance, when European Commission evaluators have met in the past to evaluate research proposals, they received printed copies which had to be returned before the panel members left, and had no computer access during deliberations. A plagiarismdetector using text-mining methods could be used instead of the current security measures. Such a system could, in principle, detect similarities to previous submissions and uncited sources using advanced document segmentation.

Only official agencies have access to confidential proposals and the funds to experiment with automated plagiarism-detectors. It is important that they should investigate these approaches to reducing the possibility of scientific misconduct.

Victor Maojo, Miguel García-Remesal, Jose Crespo Biomedical Informatics Group, Facultad de Informatica, Universidad Politecnica de Madrid, Boadilla del Monte, 28660 Madrid, Spain e-mail:vmaojo@gmail.com 